\title{
International Legal Review of the Relationship between International Tax Law and National Tax Sovereignty — Theoretical Foundation and Development Practices
}

\author{
Zuo An-lei ${ }^{*}$ \\ (Faculty of Law, University of Hong Kong, HKSAR 999077)
}

\begin{abstract}
(Abstract) By examining their theoretical basis and exercising practice relationship between national sovereignty and international tax law, it is demonstrated that the international tax law results from the coordination to exercise national sovereignty in the international law. Given the modern connotation of national sovereignty and exercising practices of international tax treaties in the international law, it is reasoned that "the international tax treaty is a kind of limitation or mitigation to national tax sovereignty" is a false pseudo-proposition; International tax regime has been established on the international law level and constitutes a part of customary international law, which is of great significance; No country has the law-making capacity or its national interest dives in the international law to change the existing international tax regime. Taking account of the exercise of the national tax sovereignty under the backdrop of the latest development practices in international tax law, it can be found that international tax cooperation makes the exercise of national tax sovereignty increase other than decrease; Countries' intensive actions to safeguard their own international taxation interests strengthen the exercise of their national tax sovereignty; New international tax topics, such as Carbon tariff and environmental taxes, will accelerate law-making revolution of international law in the field of international tax law, and thus makes the exercise of national tax sovereignty to be unified.
\end{abstract}

(Key Words) International Tax Law; National Tax Sovereignty; Exercise of Sovereignty; International Legal Review; Theoretical Foundation and Development Practices;

${ }^{*} \mathrm{PhD}$ Candidate in Faculty of Law, University of Hong Kong; LLM, National University of Singapore.

This paper is one of the academic achievements of the PRC. Ministry of Education Philosophy and Social Science Significant Subject Research Project "Study on the Legal Environment of Financial Service Intermediaries in Shanghai's International Finance Center Development and Construction"(Project NO. 11JZD009), 2012 "Shanghai University Best Graduate Academic New Star" Project, ECUPL University Academic Innovation Research Project "Study on the Latest Development of National Sovereignty Theory and Its Relationship with International Human Rights" (Project NO. 20112012). The author thanks Professor Wu Hong from East China University of Political Science and Law and Associate Professor Li Jian from Law School of Shanghai Jiaotong University for their helpful comments on this article. But the views expressed here are strictly personal and any error goes to the author. 


\section{Table of Contents}

I. Introduction

II. International Tax Law and National Sovereignty: Argument on the Dimension of International Law

A. International Tax Law Results from the Coordination to Exercise National Sovereignty in the International Law

B. "International Tax Treaty is a Kind of Limitation or Mitigation to National Tax Sovereignty" is a False Pseudo-proposition

III. International Tax Regime as International Law: Controversies and Developments

A. International Tax Regime has been Established on the International Law Level

B. It is Significant that International Tax Regime Constitutes a part of Customary International Law

C. No Country has the Law-making Capacity or its National Interest Dives in International Law to Change the Existing International Tax Regime

IV. Development Practices of International Tax Law and Exercise of National Tax sovereignty

A. International Tax Cooperation Makes the Exercise of National Tax Sovereignty Increase other than Decrease

B. Countries' Intensive Actions to Safeguard Their Own International Taxation Interests Strengthen the Exercise of their National Tax Sovereignty

C. New International Tax Topics, such as Carbon Tariff and Environmental Taxes, will Accelerate Law-making Revolution of International Law in the Field of International Tax Law, and thus Make the Exercise of National Tax Sovereignty to be Unified.

V. Conclusion 


\section{Introduction}

Over the past several decades, the Chinese international jurisprudence community is mainly focused on the following two parts of international tax law academic researches: firstly, introduction and analysis of the development or innovation of foreign tax law legal system as well as case studies of famous or significant cases' causes and consequences, and also exploration of the regional or international tax law issues on those bases; ${ }^{1}$ secondly, monographic study of some propositions or issues in the international tax law, such as academic discussion about transfer pricing, controlled or affiliated foreign company, information exchange and international cooperation, arbitration of taxation issues, tax avoidance of multinational companies, and international tax law issues within the framework of WTO. ${ }^{2}$ These studies are mainly developed from the perspective of international economic law, with analysis of characteristics and inner rules concerning tax laws and legal practices, so as to predict their development trends, the possibility and rationality of law transplants.

From one point of view, international tax law, as domestic law with its nature of public law transformed into international law and developing into a branch of international law, has strong chromatic characteristics of the nature of public law and national sovereignty. And therefore, studies and discussions from the viewpoint of public international law (particularly in the context of national sovereignty principle) certainly have good theoretical and practical impacts. Investigations of a lot of specific issues in the field of international tax law cannot be separated from the participation of the national sovereignty theories in public international law. This paper will thus stretch the international legal review from the perspective of the relation between international tax law and national tax sovereignty, from theoretical foundations to development practices, exploring and demonstrating the problems in international tax law.

Following the introduction, Section II mainly seeks to argue the international tax law and national sovereignty on the Dimension of International Law by examining their theoretical basis and exercising practices. Section III then considers the controversies and developments of international law and international tax law mechanism, taking account of the exercise of the national tax sovereignty under the backdrop of the latest development practices in international tax law. Section IV concludes the paper.

\section{International Tax Law and National Sovereignty: Argument on the Dimension of International Law}

\section{A. International Tax Law Results from the Coordination to Exercise National Sovereignty in the International Law}

In accordance with the principle of national sovereignty, national sovereignty means that it

${ }^{1}$ For example, Gu Hongmei, Review of US Newly Reform of its Federal Tax Law, Law Science Magazine 2005 (6), 113-115; see Cui Xiaojing, Study of the Administration Coordination Mechanism of International Tax Collection from the "United Bank of Switzerland" Case, Legal Science Monthly 2010(12), 46-58; see Su Hao, The Pan-American Satellite Corp. (PASC) Case and Demarcation of Multinational Operating Profit and Royalties, Wuhan University International Law Review 2004, 318-333. The author's assertion is based on all the papers in the Information Network of Peking University Column "Law Journals" attributed to sub-section "International Tax Law" in 1995-2013, which already covered most of the core journal articles.

2 For example, A Review on OECD's International Tax Arbitration Mechanism, Journal of Xiamen University (Philosophy and Social Sciences) 2012 (5), 66-74; Liao Yixin, Fu Huizhu, study of the Bank secrecy and International Tax Information Exchange Legal Issues, Gansu Social Sciences 2007 (3), 153-156; Cui Xiaojing, Study on the Construction of International Tax Coordination Legal Mechanism: Based on the Responsible Tax Sovereignty, Law Review 2010 (5), 82-87; Cui Xiaojing, Amendment to the Convention on Mutual Administrative Assistance in Tax Matters and China's response, Legal Science Monthly 2012 (7), 83-92. 
excludes any attachment to any other authorities (especially the authority of another country), and namely, national sovereignty is independent, while "independence towards internal domestics" includes the sovereignty right to national territory and the ruling right to its own citizens. ${ }^{3}$ According to the authoritative Georg Jellinek's "three elements" doctrine, there must be nationals effectively organized through national power institutions above the territory of a particular country to constitute a nation. ${ }^{4}$ All persons and properties within the national territory are dominated by the nation with territorial authority; nationality is the link connecting individuals and the nation, and the state has the sovereignty jurisdiction over the nationals through the nationality. ${ }^{5}$ Accordingly, in the exercise of the jurisdiction of a country based on sovereignty, two most basic types of jurisdiction derive: territorial jurisdiction and personal jurisdiction.

Despite that jurisdiction is based on national sovereignty, there are differences between the scope of national sovereignty and its jurisdiction. It does not mean that a country can fully exercise its jurisdiction rights under any circumstances in international law, since overlapping claims of jurisdiction has occurred and will occur a lot. ${ }^{6}$ And in accordance with "No dominance among equalities", no nation has the right to claim jurisdiction over another country. In view of the overlapping claims or the existence of so-called jurisdiction conflicts, nations have established corresponding rules for the harmonization of jurisdiction in international exchanges in consideration of international comity and facilitating international practices. ${ }^{7}$

With all those reflected in the field of international tax law, international tax law is generated in the regulation process to harmonize the simultaneous usage of personal and territorial jurisdiction conflicts. ${ }^{8}$ Taxation has the attribute of national sovereign authority of a nation, which is one of the means and manifestations of one nation to exercise sovereign rights, ${ }^{9}$ and the differences and conflicts in countries' tax jurisdiction produce issues on international tax law. ${ }^{10}$ For example, international treaties to avoid double taxation widely use the residence criteria to establish a taxation connection factor of its dominant persons or entities so as to tax, ${ }^{11}$ or the actual management and control criteria of a legal person within its territory, which are clear

${ }^{3}$ In the "Island of Palmas" (1928) case, sole arbitrator Max Huber clearly pointed out that "sovereignty means independence". See Jennings etc. edited, Oppenheim's International Law, 1st volume, 1st fascicule, translated into Chinese by Wang Tieya etc., the Encyclopedia of China Publishing House (1998), 292, 362.

${ }^{4}$ See Wolflgang Graf Vitzthum (DE), International Law, translated into Chinese by Wu Yue, Mao Xiaofei, Law Press (2002), 235-236.

5 See Wolflgang Graf Vitzthum (DE), International Law, translated into Chinese by Wu Yue, Mao Xiaofei, Law Press (2002), 236, 243.

${ }^{6}$ See Jennings etc. edited, Oppenheim's International Law, 1st volume, 1st fascicule, translated into Chinese by Wang Tieya etc., the Encyclopedia of China Publishing House (1998), 328.

7 This is not so much a real or substantial problem, as it is for the sake of convenience. See Jennings etc. edited, Oppenheim's International Law, 1st volume, 1st fascicule, translated into Chinese by Wang Tieya etc., the Encyclopedia of China Publishing House (1998), 328.

${ }_{8}$ International criminal law, international law, international administrative law, and in particular the international tax law can partially mediate the using of both personal and territorial principles which leads to conflict of laws. See Wolflgang Graf Vitzthum (DE), International Law, translated into Chinese by Wu Yue, Mao Xiaofei, Law Press (2002), 263.

9 See Guiguo Wang, International Investment Law, Law Press (2008), 366.

10 Overlapping or missing of tax jurisdiction leads to major problems of international tax law, such as international double taxation, international tax evasion and avoidance. See Cao Jianming, Chen Zhidong, Monographs of International Economic Law, Volume 6th, Law Press (1999), 65, 100.

${ }_{11}$ See generally OECD Model Convention, supra note 1, Art. 4, at 24. The first paragraph of Article 4 of the OECD Model Convention, which defines "residents," reads as follows: For the purposes of this Convention, the term "resident of a Contracting State" means any person who, under the laws of that State, is liable to tax therein by reason of his domicile, residence, place of management or any other criterion of a similar nature, and also includes that State and any political subdivision or local authority thereof. This term, however, does not include any person who is liable to tax in that State in respect only of income from sources in that State or capital situated therein; also see United States Model Income Tax Convention of Nov. 15, 2006 (2006), Art. 4.1. 
manifestations of the relationship in terms of theoretical basis and exercising practices between national sovereignty and international tax law. ${ }^{12}$

In the context of modern cross-border economic activities, the different national tax systems and tax bases lead to the need for international tax cooperation between countries. The coordination of tax jurisdiction through treaties lively demonstrated that international tax law is product of the coordination to exercise national sovereignty in the international law. ${ }^{13}$

\section{B. "International Tax Treaty is a Kind of Limitation or Mitigation to National Tax Sovereignty" is a False Pseudo-proposition}

In the modern international law, countries arrived at international treaties or agreements regarding certain matters, ${ }^{14}$ so as to comply with and practically live up to the international law rules all parties had agreed to, realizing the peaceful and rational exercise of specific sovereign powers. So, how to define and analyze the impacts of such an international treaty or convention on national sovereignty? For the purpose of this paper in the field of the international tax law, how to deal with and reason the proposition that "international tax treaty is a kind of limitation or mitigation to national tax sovereignty"? I think demonstration and elaboration of this proposition needs to be expanded to two angles: the intension of national sovereignty in the modern international law, and the practical exercise of international tax treaties.

First of all, the concept of national sovereignty has its inherent restraining factors, and national sovereignty in the modern international law is not an absolute or unlimited power.

International exchanges among countries are based on national sovereignty, while national sovereignty firstly demonstrated that a nation will only be regulated by international law. This is exactly the limitation of national sovereignty and jurisdiction within the territory boundaries: the existence of any sovereignty act of other countries is not allowed above the territory of a nation. ${ }^{15}$ To other subjects of international law, countries can (and only can) make autonomous arrangements under their own legal frameworks and authorities. Even if a country allows other countries to exercise of the sovereignty power within the territory, this kind of the national sovereignty power is derived from power transfer of that territorial country. Namely, the sovereignty power exercised above that territorial country's territory is still the original sovereign power of that country. The development in depth and breadth of international rule of law, the strengthening of the function of derived international law subjects, and expanding of adjustment objects characterized with international legal cooperation in modern international law has not

12 Taking the concept of "Permanent Establishment" as an example, the OECD Commentary on Article 7 states the generally accepted principle of double taxation conventions: "profits of an enterprise of a Contracting State shall be taxable only in that State unless the enterprise carries on business in the other Contracting State through a permanent establishment situated therein." In the absence of a PE in another State, it should not properly be regarded as participating in the economic life of that other State to such an extent that it comes within the jurisdiction of that other State's taxing rights. See generally OECD Model Convention, Art. 7.1, at 26. Article 7, "Business Profits," reads as follows: "1. The profits of an enterprise of a Contracting State shall be taxable only in that State unless the enterprise carries on business in the other Contracting State through a permanent establishment situated therein. If the enterprise carries on business as aforesaid, the profits of the enterprise may be taxed in the other State but only so much of them as is attributable to that permanent establishment".

${ }^{13}$ See Cao Jianming, Chen Zhidong, Monographs of International Economic Law, Volume 6th, Law Press (1999), 13, 23-24.

${ }^{14}$ In the argument of this article, the author uses the term "treaty" in a broad connotation, and makes no difference between itself and other treaty names, such as agreement. See Li Haopei, Introduction to the Law of Treaties, Law Press (2003), 21.

15 Obviously, laws and regulations of a country are the most important method of exercising national sovereignty and national jurisdiction. See Wolflgang Graf Vitzthum (DE), International Law, translated into Chinese by Wu Yue, Mao Xiaofei, Law Press (2002), 29, 237, 263. 
wavered the premier status of the principle of national sovereignty. ${ }^{16}$

But whether it is from the perspective of international law's birth process, developments over the times, or the properties and the general rules of law, international law is never absolute or unlimited. Firstly, from the viewpoint of the birth process of the international law, the nations established an international community social order through self-regulation (particularly by concluding treaties), acting as both the legislator and the regulated parts. ${ }^{17}$ Apparently, international law is fragile, and the national sovereignty is not absolute. This is clearly a "systemic deficiency"18 argument. Secondly, from the perspective of the developments over the times of international law, in the sense of modern international law, despite that international law is changing and expanding, the basic function has not changed as follows: to maintain justice and peace in international relations, aiming at orderly coexistence of various ethnic groups and human being. ${ }^{19}$ States conduct exchanges in an equal order under international law. In ensuring this peaceful and just order, no country is allowed to make any legislation or implementation concerning any rules, institutions or procedures unilaterally. ${ }^{20}$ After World War II, principle of national independence and equality, principle of autonomy, and the principle of prohibition to the use of force, all of which were derived from the principle of national sovereignty, constantly revised and clarified the real connotation of the national sovereignty principle. Thus, International law started from the argument between the effectiveness proof and the properties of law in the initial literatures towards more testing and development on a practical level, ${ }^{21}$ with more obvious characteristics of exchanges, coexistence, co-operation and development in international law, "consensus" becomes an important concept in international law. ${ }^{22}$ Thirdly, from the perspective of the properties and the general rules of law, international law upholds a significant function of the law: the limitation of powers and the protection of rights. ${ }^{23}$ As a basic concept in modern international law, national sovereignty, as the source of the supreme power "Zuhchstsein", necessarily implies restrictions of powers in international exchanges and self-restraint regarding violations of international law. ${ }^{24}$ Concept of absolute sovereignty is already prohibited in the international community absent of coercive force protection, and this relativity is obviously manifested in the adjacent law of international law. ${ }^{25}$

${ }^{16}$ See Wolflgang Graf Vitzthum (DE), International Law, translated into Chinese by Wu Yue, Mao Xiaofei, Law Press (2002), 15.

${ }^{17}$ See Wolflgang Graf Vitzthum (DE), International Law, translated into Chinese by Wu Yue, Mao Xiaofei, Law Press (2002), 30.

18 In accordance with Wolflgang Graf Vitzthum's viewpoints, problems in many areas of international law can be divided into two types: accidental deficiency of specific rules and systematic deficiency, and he also pointed out that in many important areas there is a lack of special provisions or there is only formal provisions, and thus some of the basic questions of international law remain to be elucidated. See Wolflgang Graf Vitzthum (DE), International Law, translated into Chinese by Wu Yue, Mao Xiaofei, Law Press (2002), 31.

${ }_{19}$ International law can neither be understood in abstract, nor being divorced from history and culture. See Wolflgang Graf Vitzthum (DE), International Law, translated into Chinese by Wu Yue, Mao Xiaofei, Law Press (2002), 36 .

${ }^{20}$ See Wolflgang Graf Vitzthum (DE), International Law, translated into Chinese by Wu Yue, Mao Xiaofei, Law Press (2002), 29.

${ }^{21}$ See Wolflgang Graf Vitzthum (DE), International Law, translated into Chinese by Wu Yue, Mao Xiaofei, Law Press (2002), 37-41.

${ }_{22}$ The intentions of all parties have occupied the central position of the international treaty law. See M. Lister, the Legitimating Role of Consent in International Law, (2011) 11(2) Chicago Journal of International Law 663. See also Jennings etc. edited, Oppenheim's International Law, 1st volume, the second fascicule, translated into Chinese by Wang Tieya etc., the Encyclopedia of China Publishing House (1998), 628.

${ }^{23}$ See Wolflgang Graf Vitzthum (DE), International Law, translated into Chinese by Wu Yue, Mao Xiaofei, Law Press (2002), 43.

${ }^{24}$ Such as National comity principle, principle of pacta sunt servanda, principle of reciprocity.

25 See Wolflgang Graf Vitzthum (DE), International Law, translated into Chinese by Wu Yue, Mao Xiaofei, 
The concept of national sovereignty in international law implies self-restraint factors, and a nation can only equally enjoy their sovereignty and freedom within the scope of international law. ${ }^{26}$ Therefore, in the field of international tax law, the meaning of national sovereignty should not be interpreted as the full exercise of jurisdiction under the principle of territorial jurisdiction and the principle of personal jurisdiction, since the national sovereign power in international tax law has its inherent limitations.

Secondly, international tax treaties in the international tax are just about the exercise and maintenance of national sovereignty from the angle of practical exercise, rather than limitation or mitigation.

Just as Justice Holmes had said: "The life of law lies in practices". International law is all the more so, without any coercive force protection mechanism. Regulations and subsequent practices of the international law regarding national sovereignty is precisely the exercise and maintenance of national sovereignty on the basis of coordination to exercise national sovereignty, and the intension or connotation of national sovereignty in international law is mostly clarified and defined through specific exercising practices, such as international treaties. The international treaty is one of the most important sources of law and patterns of manifestation in international law, and it can be said that the role of treaties in international law is just the same as the laws and regulations in the domestic law. ${ }^{27}$ Famous international treaty law scholar Li Haopei defined the concept of "treaty" with "unanimous declaration of intentions by the parties must intend to generate, change or repeal the original rights and obligations in accordance with international law" as one of the core elements. ${ }^{28}$ The exercise of the national sovereignty would be reflected whether in the negotiation, drafting, certification, signature, approval, reservation of a bilateral treaty, or other processes of a multilateral treaty. "Consensus" has become an important concept in international law, exactly and precisely because the declaration practices of intentions about national sovereignty are the direct drivers the definition of national sovereignty's connotation and development of times. The rights and obligations in the international law are the very core and essence of the international treaties. ${ }^{29}$

Take the agreement on the avoidance of double taxation as an example, the purpose of the agreement is not to authorize one nation to tax or to share the tax revenues, but define the sovereignty right over the overlapping part of jurisdiction. From the viewpoint of the taxation practices, tax base and the tax fund are divided, but from the perspective of national sovereignty in international law, in this process national sovereignty is clarified with its implementation

Law Press (2002), 29.

${ }_{26}$ As a concept of international law in the field of international law jurisprudence, national sovereignty's intension must be subject to appropriate demarcation and definition of international law. Sovereignty or freedom is not placed above the international law, but under the law, namely legitimate freedom. But this is definitely not a concept on the same dimension with the "limitation" elaborated in the following part. See Wolflgang Graf Vitzthum (DE), International Law, translated into Chinese by Wu Yue, Mao Xiaofei, Law Press (2002), $30,32$.

${ }^{27}$ See Thomas Buergenthal, Sean D. Murphy, Public International Law (3 ${ }^{\text {rd }}$ Edition), Law Press (2003), 102.

${ }_{28}^{28}$ See Li Haopei, Introduction to the Law of Treaties, Law Press (2003), 3.

29 We can also get a glimpse of it from the conservative requirements of the Treaty as documents, and refusal to recognize the "gentlemen's agreement". Although the definition of "treaty" in the Vienna Convention on the Law of Treaties provides for paper documents, but that does not affect the legal binding force of the verbal agreement. The core of a treaty is to create legal rights and obligations between the parties, and at this point, the International Law Commission considers that it is included in the "subject to international law" part of the definition of "treaty". See Li Haopei, Introduction to the Law of Treaties, Law Press (2003), 13-20; see Jennings etc. edited, Oppenheim's International Law, 1st volume, the second fascicule, translated into Chinese by Wang Tieya etc., the Encyclopedia of China Publishing House (1998), 627. 
foundations and means. ${ }^{30}$ Another example is the cooperation and assistance treaties in international tax. Seemingly, it appears that a country's tax jurisdiction extends to the territory of another nation's tax bases, but all of those are carried out with the consent of the sovereign authority of another country and the cooperation assistance of local tax authorities. In fact, those are just assignment of the sovereignty powers of this host nation, which can also be known as abroad recognition of the sovereign powers of a country in this host nation. Within this process, there is no increase or decrease of the sovereignty powers of any State, other than just changes of the exercising methods. Those horizontal rather than vertical coercive international laws do not have impacts and influences on the national sovereignty of this host nation. ${ }^{31}$

Conversely, if a country does not enter into any tax treaties in international law, and is confined to defined and exercise its sovereign power unilaterally, the results can only be express or implied sanctions and refusal to recognize from the international community. Firstly, its sovereign power claims cannot be actually exercised, and secondly sovereign powers, which would be clarified and recognized if treaties are arrived at, are in lack of recognition. This is a concrete manifestation of the principle of international cooperation in contemporary international law, which is also the practical logic why absolute national sovereignty must be abandoned. ${ }^{32}$ The premise of exercising one country's national tax sovereignty power is respects to the national tax sovereignty of other countries. ${ }^{33}$

Some scholars call this process or result of clarification and definition as "limitation" to the national sovereignty, which is not correct. Theoretical intension and practical boundaries of national sovereignty is ever-changing, and its evolution and development process is objective, natural, without any deliberate or blunt changes. ${ }^{34}$ Those new expansions or contractions of national sovereignty are just proofreading and metrics to itself, which are inspects to its noumenon rather than external constraints or limitations.

In summary, the proposition that "the international tax treaty is a kind of limitation or mitigation to national tax sovereignty" is not true.

\section{International Tax Regime as International Law: Controversies and Developments}

As to whether international tax regime ${ }^{35}$ has been established in international law, scholars of international tax law uphold many different points of view.

Reuven Avi-Yonah is one of the representative scholars who are in favor of the standpoint that there is a coherent international tax regime in international law. Reuven Avi-Yonah considers that there is already one set of international tax law system in contemporary international law, which is reflected in the tax treaty network and domestic laws of nations, and they are an

${ }^{30}$ Of course, the unequal treaties or economically, politically coercion signed treaty is not in the scope of the discussion. They are in violation of the basic principles of international law, and therefore invalid. See Wolflgang Graf Vitzthum (DE), International Law, translated into Chinese by Wu Yue, Mao Xiaofei, Law Press (2002), 668.

${ }^{31}$ See Wolflgang Graf Vitzthum (DE), International Law, translated into Chinese by Wu Yue, Mao Xiaofei, Law Press (2002), 35 .

32 National sovereignty provides the possibility for international co-operation, but international cooperation does not change the essences and nature of national sovereignty. See He Zhipeng, Basic Theories of International Economic Law, Social Sciences Academic Press (2010), 117; See He Zhipeng, Legal regulation of the Globalized Economy, Tsinghua University Press (2006), 163-166, 170-172.

33 See Cui Xiaojing, Study of the Administration Coordination Mechanism of International Tax Collection from the "United Bank of Switzerland" Case, Legal Science Monthly 2010(12), 48.

${ }^{34}$ See He Zhipeng, Legal regulation of the Globalized Economy, Tsinghua University Press (2006), 163.

35 See Reuven S.Avi-Yonah, International Tax as International Law: An Analysis of the International Tax Regime, Law Press (2008). 
important part of international law (including international treaties and international customary law); countries have not liberal power to adopt optional international tax rules, and they can only operate within the scope of this system; international tax customary law has been formed, and we should not deny the existence of widely recognized, binding international tax rules, which can be abandoned only when material and significant national interests are at risk. ${ }^{36}$ At the same time, many opponents argue that there is no international tax regime established. ${ }^{37}$ They think that a country can still take flexible tax measures under the constraints of the existing international treaties. Meanwhile, opponents also acknowledged that there are a large number of new international coordination mechanisms in the field of international tax law. It is likely that a motivating factor in this harmonization is that, by adopting international norms in taxation, states allow their taxes to interface neatly with the taxes of other states and thereby prevent undesirable policy outcomes internationally. ${ }^{38}$

Moreover, despite that dissenters consider that international tax regime does not exist in the international law, but efforts to build an international tax legal regime should be supported. However, the process of successfully constructing the international tax regime is not simply regarding the rules appeared in the field of international tax law as international law. Different constitutional background and needs of all countries (especially China) can only be taken into account by the building a comprehensive and accommodating mechanism beyond existing international tax legal concepts. ${ }^{39}$

It is difficult to resolve this argument of the existence of international tax regime. There into, China, as a special factor and example in the reasoning and deliberation process, got many attentions from international scholars. After all, China represents an institutional context which is significantly different from other major economies in that what currently may be seen as international norms in taxation are not suited to it in any substantial sense. The solution to this cannot lie in "making" China comply. Its institutional context does not allow for this and there is evidence that it will not simply adopt undesirable international law even when it can. The solution must lie in accommodating it. ${ }^{40}$ Indeed, China represents such an important part of the world economy that, without it implementing any international regime, there can be no international regime. Analysis will be made for this view in this section.

\section{A. International Tax Regime has been Established on the International Law Level}

I believe that, without any doubt, International tax regime has been established on the international law level. Supporters like Avi-Yonah have already demonstrated and provided many grounds of arguments. On the level of international exchanges, countries in the law-making process of domestic tax laws, regulations or the implementation rules of tax measures, as well as

${ }^{36}$ See R. Avi-Yonah, International Tax as International Law, 1st edition (CUP, 2007); R. Avi-Yonah, "Tax Competition, Tax Arbitrage and the International Tax Regime" (2007) University of Michigan Law \& Economics, Olin Working Paper No.07-001; University of Michigan Public Law Working Paper No.73. See also Reuven S.Avi-Yonah, International Tax as International Law: An Analysis of the International Tax Regime, Law Press (2008).

37 See H. David Rosenbloom, International Tax Arbitrage and the "International Tax System",53 TAX L. REV. 137 (2000); see H. David Rosenbloom, Cross Border Arbitrage: The Good, The Bad and The Ugly, 85 Taxes 115 (2007); see H. David Rosenbloom, the David R. Tillinghast Lecture International Tax Arbitrage and the "International Tax System, 53 Tax L. Rev. 137.

${ }^{38}$ See Nolan Cormac Sharkey, International tax as international law and the impact of China, B.T.R. 2012 (3), 271.

${ }^{39}$ See Nolan Cormac Sharkey, International tax as international law and the impact of China, B.T.R. 2012 (3), 269.

40 See Nolan Cormac Sharkey, International tax as international law and the impact of China, B.T.R. 2012 (3), $275-277$. 
scholars' academic researches and expositions in the field of international tax regime, will comply with the general principles of international tax law, such as the principle of single tax, principle of interests, principle of non-discrimination, principle of arm's length transaction. Under the guidance of the OECD Model and the United Nations Model, many bilateral tax treaties to address the avoidance of double taxation have become a part of customary international law. At the level of a nation, some scholars have pointed out that, the reality is that there will be an income tax regime in a particular state together with the relevant executive bodies and these will be subject to jurisdictional limits. For this reason international and cross border businesses and transactions are not simply subjected to a state's "international tax" rules. They are subjected to its tax regime in its entirety. ${ }^{41}$ But we can clearly see that the development of the national tax laws are obviously under the guidance of international tax regime norms, leading national tax laws to be more homogeneous, and thus opponents' so-called phenomenon that "different domestic rules, and free choice of measures" no longer exists. ${ }^{42}$ The integration of the international tax laws promotes the process of countries' domestic taxation reform and more homogeneous trend of global tax laws, and it is difficult to imagine that a country completely ignores the international tax regime and its rules, or become contrary to it, in the development of their domestic new tax laws. ${ }^{43}$

Opponents pointed out that, on a practical level, from the standpoint of individual transactions it is difficult to identify the existence of any international tax regime. However, as Avi-Yonah had said, we can recognize and discuss the existence of the "is not" phenomenon in practice, but we cannot deny the existence of "should be" on the national policies and legal researches level. The establishment of the international tax regime will not collapse just because some subtle differences in the practices. And in my opinion, compared to "should be" and "already is", the number of this "is not" phenomenon is just a drop of ink in the Pacific Ocean.

Of course, the establishment and existence of the international tax regime neither means that the international tax regime is already perfect with nothing left to be improved, nor it means that the future development and evolution of international tax regime has been stalled. Instead, it is proclaimed that a good foundation and beginning for the "rule of law" in international tax regime. Future international tax rules revolution and practical gambling among the world's major economies are still noteworthy.

\section{B. It is Significant that International Tax Regime Constitutes a part of Customary International Law}

Scholars have put forward that, as with many instances of international law, a more relevant endeavor than considering whether there is an international regime is to consider whether these international tax customs and indeed tax customs generally should be international law. ${ }^{44}$ From a different angle, what merit is there in viewing currently existing and widely spread tax practices as being obligatory on states?

\footnotetext{
${ }^{41}$ See Nolan Cormac Sharkey, International tax as international law and the impact of China, B.T.R. 2012 (3), 275.

${ }^{42}$ For example, in terms of anti-tax avoidance, the domestic practices of China, USA and Switzerland tend to be uniform. Apparently, those unanimous actions without prior coordination are conducted under the lead of international legal models. See Kevin Holmes, The politics of the improper use of double tax treaties: China waves red flags, B.T.R. 2011, 3, 307-339.

${ }_{43}$ Taking USA and German changes in the practices concerning Anti-discrimination principle as an example, it can be witnessed that the international tax regime has pressed domestic laws to be convergent and similar. See Reuven S.Avi-Yonah, International Tax as International Law: An Analysis of the International Tax Regime, Law Press (2008), 4.

44 See Nolan Cormac Sharkey, International tax as international law and the impact of China, B.T.R. 2012 (3), 272 .
} 
The obvious answer to the first question, I believe, is that international tax regime and tax law practice customs constitute a part of international (customary) law. To the second question, I think that the international tax regime mechanisms constitute customary international law it is of great significance and has far-reaching impacts that international tax regime constitutes a part of international customary law.

If tax norms in international law are regarded as part of international customary law, tax efficiency, fairness and integrity will be more likely to be achieved. The phenomena of double taxation or double non-taxation will be reduced. Countries taxation claims on cross-border activities will be clarified and coordinated. In view of the fact that taxpayers entering any new borders are faced with a familiar tax environment, the reliability of the international economy will be significantly increased. ${ }^{45}$ Taxpayers' cross-border arbitrage or treaty shopping will be greatly eliminated, and also international tax avoidance and tax evasion are correspondingly reduced. Establishing an international tax regime in a globalized world economy will bring significant benefits. ${ }^{46}$

\section{No Country has the Law-making Capacity or its National Interest Dives in International Law to Change the Existing International Tax Regime}

Firstly, no country has the law-making capacity in the international law to change the existing international tax regime.

Despite that there seems to be little evidence that states feel compelled to follow many of the principles outlined by Avi-Yonah when it does not suit their interests, ${ }^{47}$ apparently, no country can repeatedly be contrary to international tax law, thus changing the existing international taxation regime. This law-making capacity in the international law does not exist. On the one hand, any country's acts in violation of the existing basic principles and rules only are only few cases, which will not constitute changes or amendments to the rules of international law; on the other hand, contemporary international tax rules are almost uniform and convergent, so are the level of international treaties and principles as well as domestic tax rules. ${ }^{48}$ Even with this existence of such different rules and practices between the international and domestic level, many countries are pressed to compromise in accordance with international tax rules of customary law in the international tax regime. ${ }^{49}$ More and more intensive international treaty network makes this

${ }^{45}$ See Leonardo F.M. Castro, Problems Involving Permanent Establishments: Overview of Relevant Issues in Today's International Economy, 2 Global Bus. L. Rev. 125, 2 GLBUSLR 125 (Sprg 2012), 157.

${ }_{46}$ See Eric A. Posner, International Law: A Welfarist Approach, (2006) 73(2), The University of Chicago Law Review, 487-543; see Nolan Cormac Sharkey, China's tax treaties and beneficial ownership: innovative control of treaty shopping or inferior law-making damaging to international law? B.F.I.T. 2011, 65(12), 655-661. 272.

47 See Nolan Cormac Sharkey, International tax as international law and the impact of China, B.T.R. 2012 (3),

48 See Cao Jianming, Chen Zhidong, Monographs of International Economic Law, Volume 6th, Law Press (1999), 128-130.

49 An important example is that "the taxation right of the State where the permanent establishment is situated does not extend to profits that the enterprise may derive from that State but that are not attributable to the permanent establishment." Several countries have adopted what is known as the principle of general "force of attraction" by which "income such as other business profits, dividends, interest and royalties arising from sources in [the country's] territory was fully taxable by them if the beneficiary had a permanent establishment therein, even though such income was clearly not attributable to that permanent establishment." The amended OECD

Commentary makes it clear that the general force of attraction approach has now been rejected in international tax treaty practice. Avoiding the force of attraction approach is important and possibly of immediate application for the international tax practitioner in many countries. See OECD, Ctr. for Tax Pol'y \& Admin., Revised Discussion Draft of a New Article 7 of the OECD Model Tax Convention 8 (Nov. 24, 2009-Jan. 21, 2010), available at http://www.oecd.org/dataoecd/30/52/44104593.pdf, last visited on 30 March 2013; OECD Model Tax Convention: 50 Years Young, 35 Deloitte Belg. Tax Q., 9, 11 (Jan. 2009), available at http://www.deloitte.com/assets/Dcom-Belgium/Local\%20Assets/Documents/Quarterly-Jan09.pdf, last visited on 
assimilation become international treaty obligations, and no room for international law-making capacity to create new rules.

This is in line with the economic considerations of cost-benefit model analysis regarding the national legal system, and also is the inevitable logical results of the deepening of contemporary international "rule of law". The United States, China and other major economies are bound to carry out international cooperation and exchanges in accordance with the core contents and the basic framework of international tax treaty models. ${ }^{50}$

Secondly, no country has its national interest dives to change the existing international tax regime.

Some international law scholars submitted that, as a result of the scale of its economy and of its population, the extent to which China adopts or follows prima facie international law will impact significantly upon international law. This impact goes beyond the limit of those who only deal with China. More significantly, it is difficult to envisage something being regarded as international law if such a large part of the world's economy does not feel the obligation to follow it. In other words, the actions of China have the potential to threaten the very existence of established norms and customary international law everywhere. ${ }^{51}$

I cannot agree with this kind of viewpoint. First of all, as explained in the above, although every country has its national tax sovereignty on the basis of the principle of national sovereignty, but the specific methods exercise have already been limited and demarcated, with no room for international law law-making. Moreover, and more importantly, does China have its drives of national interests to change the existing international tax regime? Which country in the world has the drives of national interests to completely change the existing international tax regime?

The answers to those two questions clearly are both negative. Firstly, although there are some differences regarding the value orientation and distributing the benefits amid the coordination in the tax jurisdiction in the present OECD and United Nations Models for international tax treaty, the basic contents and the main framework are not essentially different, and the differences are gradually narrowing. ${ }^{52}$ Emerging as the largest developing country across the globe, China needs to gradually rebalance in the protection of outbound investments interests and attraction of foreign investments, and China should begin to pay more attention to how to maintain its own overseas investment interests related to international taxation issues. The existing rules have already highlighted the interests of developed and developing countries in the international taxation respectively and thus there is no need to create a new system of rules or a new regime of international law. Secondly, "hide your capacities and bide your time", "concentrate on domestic economic development and political reform" are still Chinese major national agenda and goal. Although promoting the international political and economic order march in a more equitable and democratic direction has been China's international aspirations, the creation of completely new international rules and principles is not an ideal option, since it may be faced with obstruction and resistance that China is always trying to avoid. Under the context of multi-polarization and

30 March 2013.

${ }^{50}$ For example, in many instances the New Zealand Treaty network adopts many of the characteristics outlined in the OECD Model for art 4 to make up to the provisions of art 4 in New Zealand's Treaty network. See Jeremy Beckham, Craig Elliffe, The Inconvenient Problem with New Zealand's Foreign Trust Regime, 18 NZJTLP 166, (Jun 2012).

${ }_{51}$ See Nolan Cormac Sharkey, International tax as international law and the impact of China, B.T.R. 2012 (3), 275.

52 See Cao Jianming, Chen Zhidong, Monographs of International Economic Law, Volume 6th, Law Press (1999), 128-130. 
globalization, it is the same with any other countries.

Of course, this argument does not imply the author thinks that China should fully accept the existing international tax regime. Every country can still continue to promote the fair and democratic reform of international tax regime. And also, international tax regime do still have much room left for future improvements in its inclusivity and universality, ${ }^{53}$ while building of future system should do more to coordinate the sovereign powers of the world's major economies, especially considering the economic benefits of big emerging developing countries such as the "BRICs". From a certain angle, there is a singular practical advantage in arguing for international norms such as "international tax" law (and ultimately an international regime) in principle rather than presenting the regime identified by Avi-Yonah as a fait-accompli. This advantage is that, in arguing that particular principles should be regarded as international law, there is significantly greater scope for the exclusion of undesirable or controversial principles than there is when an established obligatory regime is simply presented. An open debate about what may constitute a future regime allows for far greater prospects of success in creating the necessary sense of obligation amongst the necessary states. ${ }^{54}$ Therefore, open discussion about the mechanism contents will promote the balance of interests in the international tax regime and its universal acceptance, which definitely has positive effects in the promotion of "rule of law" in international taxation.

\section{Development Practices of International Tax Law and Exercise of National Tax sovereignty}

\section{A. International Tax Cooperation Makes the Exercise of National Tax Sovereignty Increase other than Decrease}

The gradual establishment and constant improvements of international tax cooperation mechanisms are an important aspect of international tax legal regime in recent years. ${ }^{55}$ For example, In 2010, the OECD and the Council of Europe made amendment to Amendment to the Convention on Mutual Administrative Assistance in Tax Matters; ${ }^{56}$ the "United Bank of Switzerland" case in 2008 started changes to the coordination of cross-border tax collection and information exchange ${ }^{57}$ after 2008 transparency and information exchange standards drafted and developed by OECD are widely recognized and adopted in the treaties for the international regulation of tax havens; ${ }^{58}$ and so on. In this section I am not intending to analyze any specific

\footnotetext{
${ }^{53}$ See Adam H. Rosenzweig, Thinking Outside the (Tax) Treaty, 2012 Wis. L. Rev. 717.

${ }^{54}$ See Nolan Cormac Sharkey, International tax as international law and the impact of China, B.T.R. 2012 (3), 274.

${ }^{55}$ See Nyree Craig, Cross-border assistance in the collection of taxes, Tax J. 2012, 1131, 21-23.

56 See Achim Pross and Raffaele Russo, The amended Convention on Mutual Administrative Assistance in Tax Matters: a powerful tool to counter tax avoidance and evasion, B.F.I.T. 2012, 66(7), 361-365; see Walter C. Keiniger and Valeria D'Alessandro, Argentina signed the OECD's Multilateral Convention on Mutual Administrative, T.P.I.R. 2013, 40(1), 19-23.

${ }^{57}$ See Achim Pross and Raffaele Russo, The amended Convention on Mutual Administrative Assistance in Tax Matters: a powerful tool to counter tax avoidance and evasion, B.F.I.T. 2012, 66(7), 361-365; see Walter C. Keiniger and Valeria D'Alessandro, Argentina signed the OECD's Multilateral Convention on Mutual Administrative, T.P.I.R. 2013, 40(1), 19-23.

58 See Tax Planning International Review, Tax laws in some countries do not meet global standard: OECD, T.P.I.R. 2011, 38(2), 32-33; Mark Kennedy and David Lyons, Tax authorities put pressure on OFCs, Offshore Red 2008, 13(1) Supp (The OFC Report 2008), 10-11; John Greenwood, IOSCO: a global force in the offshore world? Offshore Red 2008, 13(1) Supp (The OFC Report 2008), 12-13. (The papers discuss the practices of the International Organisation of Securities Commissions (IOSCO), praising its work in setting standards for transparency and information exchange as compared with OECD initiatives targeting harmful tax regimes and focusing on blacklisting.)
} 
events or regime, but consider how those development practices in international tax cooperation affect the exercise of national tax sovereignty.

Take 2008 "United Bank of Switzerland" case for example, the UBS case directly reflects the significant differences between the United States and Switzerland regarding the bank secrecy regime in domestic laws, and following or resulted conflicts and dilemmas in the issue of international tax avoidance. They mainly manifested as different definitions in bank secrecy regimes on the scope of the protection of client's tax information between the two countries, divergences in the identification and processing of relevant circumstances between the two countries, and the differences about the regulation of tax avoidance in criminal law between the two countries. ${ }^{59}$ It can be said that the core issue of the case is not actually legal problems in the field of international tax law, since in a more specific sense it is the collision of domestic laws on the basis of different national identities and national economic interests, and financial and criminal factors included are more obvious and sharp. But its final result is an important legal issue in international tax law: how to regulate the global tax havens from the perspective of international tax law? Personally, I believe that so-called "domestic", "neutral" domestic laws in those tax havens are actually a disguised form of refusal or deviation to international tax law and the international "rule of law", and those "tax havens" will inevitably bear more and more the regulatory pressure from international treaties and the international community. In this case, the Swiss domestic laws are obviously a potential erosion of national tax sovereignty of the United States, which is completely different from the conflicts between national tax sovereignties of the two countries. Undoubtedly, it requires the binding international tax treaties to play a more positive role on the level of international law in the maintenance of international tax sovereignty.

Although the result is just to settle one case, but the future trend to exercise national tax sovereignty demonstrated by it is clear: the implementation of any domestic law of any country cannot be at the expense of other countries' national tax sovereignty, and international tax cooperation will promote the exercise of national tax sovereignty while national tax sovereignty and tax benefits will increase other than decrease.

\section{B. Countries' Intensive Actions to Safeguard Their Own International Taxation Interests Strengthen the Exercise of their National Tax Sovereignty}

Since the subprime financial crisis in 2008, a clear trend has strongly emerged in the legislative, judicial and administrative practices of domestic tax laws in the United States, China and other world's major economies to better protect domestic tax interests, and to safeguard national tax sovereignty. This section will analyze and demonstrate this trend with the application of anti-abuse rule as an example.

Effective from January 1, 2008, the new Enterprise Income Tax Law of the People's Republic of China contains a general anti-avoidance clause, denying the legitimacy of the abuse of tax treaties by means of international corporate structures, so as to resolve the international tax avoidance problem of using a conduit company to derogate the tax base under the jurisdiction of source of income. ${ }^{60}$ And this anti-abuse clause have been applied and implemented in the legal

59 See Cui Xiaojing, Study of the Administration Coordination Mechanism of International Tax Collection from the "United Bank of Switzerland" Case, Legal Science Monthly 2010(12), 49-51.

${ }^{60}$ Article 47 of the 2008 Enterprise Income Tax Law of the People's Republic of China: "Where an enterprise makes any other arrangement not for any reasonable business purpose, if its taxable revenue or income decreases, the tax organ has the power to make an adjustment through a reasonable method." Moreover, in the newly issued Regulation on the Implementation of the Enterprise Income Tax Law of the People's Republic of China, Article 120 stipulated that: "The expression 'not have a reasonable commercial purpose' as used in Article 47 of the EIT 
practices of China. ${ }^{61}$ As for whether this innovation is innovative control of treaty shopping or inferior law-making damaging to international law, it is clear that the voices of support account for the majority. ${ }^{62}$

Firstly, international treaties provide legal basis for the rationality and legitimacy of the anti-abuse rule. ${ }^{63}$ Paragraph 7.1 of the OECD Commentary on Article 1 states that attempts by taxpayers to abuse the tax laws of a State by exploiting differences in various countries' laws: may be countered by provisions or jurisprudential rules that are part of the domestic law of the State concerned. Such a State is then unlikely to agree to provisions of bilateral double tax conventions that would have the effect of allowing abusive transactions that would otherwise be prevented by the provisions and rules of this kind contained in its domestic law. Also, it will not wish to apply its bilateral conventions in a way that would have that effect. ${ }^{64}$ Obviously, Chinese State Administration of Taxation's actions are consistent with those provisions and interpretations.

Secondly, practical judicial cases in civil law countries and common law countries also provide international legal support for rationality and legitimacy of this anti-abuse rule. In the US "Aiken Industries" when to apply international treaties, ${ }^{66}$ and clearly states that: "In deciding whether a given taxpayer in a specific instance is protected by the terms of a treaty, we must 'give... the specific words of a treaty a meaning consistent with the genuine shared expectations of the contracting parties,' and in so doing, it is necessary to examine not only the language, but the entire context of agreement". ${ }^{67}$ Besides, "Holding ApS" ${ }^{68}$ case occurred in the Swiss which is a country of continental law system, and the Swiss Federal Court holds that: "good faith, [and] the aim and purpose of a convention are to be taken into account when an international convention is applied. Every contracting state can expect that the other contracting state acts in accordance with these principles.... This includes the tackling of abuses [b]ecause the prohibition of abuses is part of the principle of good faith....It prohibits the use of an institute of law against its purpose to realise interests which are not protected by it....Accordingly, the prohibition of an abuse of rights as regards conventions is... recognised... without being necessary to adopt an explicit provision in the respective convention". ${ }^{6}$

From practices and cases in different countries analyzed above, we can see that the method of liberal construction principle to interpret and strictly confined to apply the international tax treaties is widely used in order to ensure the interests of the international tax sovereignty. Even if there is no clear clause embodying the anti-abuse rule in the bilateral tax treaties, the contracting States and its courts tend to maintain their national sovereign interests through the use of the interpretation methods in the interpretation process of treaties.

\footnotetext{
Law refers to that the main purpose is to reduce, exempt or defer the payment of taxes."

${ }^{61}$ Xinjiang, Chongqing, Jiangsu and Fujian cases, see Kevin Holmes, The politics of the improper use of double tax treaties: China waves red flags, B.T.R. 2011, 3, 316-321.

62 See Nolan Cormac Sharkey, China's tax treaties and beneficial ownership: innovative control of treaty shopping or inferior law-making damaging to international law? B.F.I.T. 2011, 65(12), 655-661; Kevin Holmes, The politics of the improper use of double tax treaties: China waves red flags, B.T.R. 2011, 3, 307-339.

${ }_{63}$ Paragraph 7.1, paragraphs 9.2 and 9.3 of the OECD Commentary on Article 1. See OECD Committee on Fiscal Affairs, Model Tax Convention on Income and on Capital (Paris: OECD, 2010) (OECD Model).

${ }_{64}$ OECD Model, Commentary on Art.1 [7.1].

65 Aiken Industries Inc. v Commissioner of Internal Revenue [1971] 56 TC 925 (US).

${ }^{66}$ See Jordan v Tashiro [1928] 278 US 123, 127.

67 See Aiken Industries, [1971] 56 TC 925 (US), 933; Citing Maximov v United States, [1963] 373 US 49.

${ }^{68}$ See A Holding ApS v Federal Tax Administration, (2005) 8 ITLR 536.

69 See A Holding ApS v Federal Tax Administration, (2005) 8 ITLR 536, 557.
} 
Meanwhile, OECD in this area never tries to pre-empt and establish rules that erode national sovereignty. The tendency of countries to strongly maintain their own international tax benefits is increasingly clear, and the corresponding measures of those countries in the context of the economic crisis directly lead to the gradual strengthening of national tax sovereignty. ${ }^{70}$ Future practices of the United States and China will more clearly reflect and demonstrate this point. ${ }^{71}$

\section{New International Tax Topics, such as Carbon Tariff and Environmental Taxes, will Accelerate Law-making Revolution of International Law in the Field of International Tax Law, and thus Make the Exercise of National Tax Sovereignty to be Unified.}

Under the backdrop of energy crisis and global environmental crisis of the times, national responses and solutions include new taxes such as resource taxes, environmental taxes and windfall profit taxes. ${ }^{72}$ EU's aviation carbon tariff leads to generally controversial discussions over international tax issues around the world, and its compatibility with the current international trade system and the international climate legal regime is questioned by a number of international law scholars. ${ }^{73}$

Putting specific environmental issues and gambling of national interests aside, I believe that this type of new international tax disputes will certainly accelerate international law-making in the field of international tax law, resulting homogeneous trend to unity in the exercise of national tax sovereignty. There are three reasons as follows. Firstly, in the context of economic globalization and the inseparability of environmental issues, the provisions of those domestic tax laws will inevitably be reflected and transformed into the international law level, and it is needed to quickly develop regional and global international treaties to achieve compromise of interests in the form of legal regulation as international law. Secondly, the trend in the development of the present international tax law is the coordination, cooperation and progressive unification of to exercise national tax sovereignty, and thus it is the same with new problems in international tax law. ${ }^{74}$ Thirdly, environmental protection, as an issue in international law with great controversies and deeply divided claims, forebodes that the international "rule of law" process in this field is long and tortuous, and sometimes even partly regressive. But it does not change the trend to exercise national tax sovereignty under the regulation of international law, and it will only exacerbate the contingency of legal changes and the complexity in compromising the interests.

${ }^{70}$ For example, US President Barack Obama announced proposals to "crack down on illegal overseas tax evasion, close loopholes, and make it more profitable for companies to create jobs here in the United States," and to ensure that companies are not rewarded "for moving jobs off our shores or transferring profits to oversees tax havens". See Press Release, Remarks by the President on Int'l Tax Policy Reform (May 4, 2009), http://www.whitehouse.gov/the_press_office/Remarks-By-The-President-On-International-Tax-Policy-Reform/.

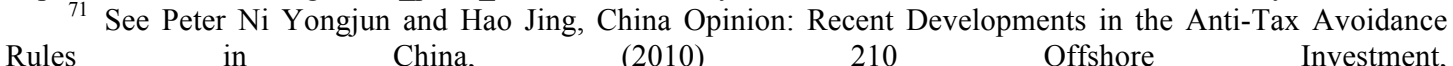
http://www.offshoreinvestment.com/current_issue/opinion210.html, last visited on 5th April, 2013.

72 See Zhan Tao, Application of Arbitration for Tax Disputes in International Investment, Studies in Law and Business 2012(5), 79.

${ }^{73}$ See Gabrielle Marceau, The WTO in the emerging energy governance debate, G.T. \& C.J. 2010, 5(3), 83-93; Lawrence L. Herman (2009), Energy trade, carbon emissions and the WTO, J.W.E.L. \& B. 2009, 2(3), 196-218; Paul-Erik Veel, Carbon Tariffs and the WTO: An Evaluation of Feasible Policies, J Int Economic Law (2009) 12 (3): 749-800; Ernst-Ulrich Petersmann, The Future of the WTO: From Authoritarian "Mercantilism" to Multilevel Governance for the Benefit of Citizens? 6 Asian J. WTO \& Int'l Health L \& Pol'y 45 (2011).

${ }^{74}$ Taking the concept of a PE is fundamental in international taxation as an example, there is an increasing need to clarify and harmonize the PE concept and requirements worldwide through tax treaties, either by adding and reviewing the wording of Model Conventions such as the OECD, UN and U.S. versions, or by expanding the Commentaries and Technical Explanations to them on current important matters. See Leonardo F.M. Castro, Problems Involving Permanent Establishments: Overview of Relevant Issues in Today's International Economy, 2 Global Bus. L. Rev. 125, 2 GLBUSLR 125 (Sprg 2012), 156-157. 


\section{Conclusion}

Norms of international law are produced by the States in accordance with its sovereign authority and power. In modern international law, jurisprudence of international law's significance as a means of the existence of international rules and contents of international law are disappearing, jurisprudence of international law is increasingly confined to the interpretation of international law. ${ }^{75}$ Just as Wolfgang Friedmann had said: "it is today a paramount task of doctrine to reassess the validity of long held assumptions, to articulate the changes in the structure of international law and society that must prepare the way for a far-reaching reformulation and modification of the rules of international law. [...] [T] he bolder advances, the development of new concepts and approaches, must remain the work of individual scholars", ${ }^{76}$ new studies should continue to backtrack and try to reconstruct the basic theories on the basis of thorough overviews.

This paper examines some theoretical basis and development practices in international tax law from the perspective of national sovereignty, and it tries to provide a constructive new perspective, or new ideas. The conclusions may not be important, since it's just a maneuver to end the analysis and argument decently when you're too lazy to continue to investigate and think about it. ${ }^{77}$ Those angles of concerns and research methods may be beneficial, since revisits to basic theoretical issues help us to determine or adjust the heading of the specific rules in international law.

${ }^{75}$ See Wolflgang Graf Vitzthum (DE), International Law, translated into Chinese by Wu Yue, Mao Xiaofei, Law Press (2002), 70-71.

${ }^{76}$ See Wolflgang Graf Vitzthum (DE), International Law, translated into Chinese by Wu Yue, Mao Xiaofei, Law Press (2002), 71.

$77 \mathrm{See} \mathrm{Su} \mathrm{Li}$, The Rule of Law and its Local Resources, China University of Political Science and Law Press, 2004 edition, Preface "What is your contribution?", VIII. 